\title{
History Teacher Readiness in Applying Historical Thinking Skills in Secondary School
}

\author{
Khairunnajwa binti Samsudin', Mohd Mahzan bin Awang², Anuar bin Ahmad ${ }^{3}$ \\ 1 Faculty of Education, National University Of Malaysia, Selangor \\ 2 Faculty of Education, National University Of Malaysia, Selangor \\ 3 Faculty of Education, National University Of Malaysia, Selangor \\ ${ }^{1}$ najwasamsudin90@gmail.com, ${ }^{2}$ mahzan@ukm.edu.com, 3anuarahmadukm@gmail.com
}

\begin{tabular}{ccc}
\hline Received & Accepted & Published \\
$06 / 04 / 2017$ & $09 / 06 / 2017$ & $31 / 07 / 2017$ \\
\hline & DOI \\
& $10.26523 /$ yupa.v1i2.42 \\
\hline
\end{tabular}

Abstract This article aims to study on the readiness of history teachers to inculcate historical thinking skills among students. This study focused on four aspects which includes 1) Procedural Knowledge, and 2) Pedagogical Knowledge. Thus, to achieve the purpose of the study, quantitative methods are used. Questionnaires were distributed to 30 history teachers in a secondary school in Batu Pahat district. The results showed that there were no significant differences between teachers who were trained to teach History and those who are not. However, there was a significant difference between teachers with ten years of teaching experience with the readiness of history teachers.

Keywords: Historical Thinking, Procedural Knowledge, Chronology, Interpretation, Imagination, Rationalization

Abstrak Artikel ini bertujuan untuk mempelajari kesiapan guru sejarah dalam menanamkan keterampilan berpikir historis di kalangan siswa. Penelitian ini difokuskan pada empat aspek yang meliputi 1) pengetahuan prosedural, dan 2) pengetahuan pedagogis. Dengan demikian, untuk mencapai tujuan penelitian, metode kuantitatif digunakan. Kuesioner dibagikan kepada 30 guru sejarah di sekolah menengah di Kabupaten Batu Pahat. Hasil penelitian menunjukkan bahwa tidak ada perbedaan yang signifikan antara guru yang dilatih untuk mengajar sejarah dan mereka yang tidak. Namun, ada perbedaan yang signifikan antara guru dengan sepuluh tahun pengalaman mengajar dengan guru sejarah dalam masa persiapan.

Kata kunci : Pemikiran Historis, Pengetahuan Prosedural, Kronologis, Interpretasi, Imajinasi, Rasionalisasi. 


\section{INTRODUCTION}

Basically, History subjects are often classified as a boring subject to students. However, if the teaching and learning process of History is implemented in the context of the true history of History, the issue of History as a boring subject will not become an issue. This is because, History teaching and learning not only focuses on the mere presentation of facts, but it also includes inquiry skills and thinking about History-thinking Skills. Thus, this article is being carried out to look at the level of readiness of History teachers in applying the History of Thinking Skills to students in line with the objectives of the Malaysian Ministry of Education.

Generally, there are many definitions of the History Thinking Skills by scholars, both in History and History education. One of the famous scholars is Tholsfen. According to Tholsfen in Historical Thinking: An Introduction (1967), History's thinking is based on History's meaning by Collingwood, all of which is a history of thought. For Tholsfen, History's thinking is divided into four essential elements. First, it has an argument and a rational approach. Second, emphasizing the accuracy of the concept of time (chronology). Third, emphasizing the element of causality and the latter is by establishing continuity based on a significant event.

According to Wineburg in A Partial History: An Essay Review of Teaching and Learning History in Elementary Schools (1998), Historical Thinking is an ongoing process of thinking. In the Historical Thinking and Other Unnatural Acts: Charting The Future of Teaching Past (2001), he added that the process of continuous thinking should involve collecting activities by individuals, reading and analyzing historical evidence either from the first source or the second source. This step seeks to see individual efforts to build a self-understanding of an event or character. It also shows the maturity of a person in connecting the past and present.

While, VanSledright through his article on The Importance of Historical Positioning to Thinking About and Teaching History, he pointed out that historical thinking requires structural knowledge to answer 'what' questions and procedural knowledge to answer 'how' questions in History education. The Vansledright opinion was supported by Seixas in Historical Understanding Among Adolescents in a Multicular Setting (1993). He divided the historical thinking into three parts. First, identify the events that left the historical impression to answer the question of 'what' refers to the important thing in the past. The 'why' question refers to the rationale of past importance. The second is through historical epistemology. In this case, students need to have knowledge of the past as the basis of knowledge. This requires the ability of the teacher to translate it such as how to balance the relationship between character, empathy and moral values.

History is one of the core subjects in the Secondary School Curriculum (KSSM). The Malaysian government's decision to make History as a subject of passing the History since 2013 has indeed received a positive reaction by some communities, especially to History teachers. 
Basically, the teaching and learning of History in KSSM in Malaysia has its own objective. Among the aims is to produce students who have not only empirical knowledge of historical developments in Malaysia and global history but also to stimulate student thinking throughout their teaching and learning process.

This is in line with what has been stated by Wan Mohd Zaid Mohd (1991). In the Malaysian context, he states that History is an intellectual inquiry skill and has an open and critical thinking value. The open-minded value is intended to be applied in describing historical evidence and interpretation based on existing historical facts. His statement was supported by Maharom in the Analysis of Historical Thinking Skills in the Materials of the Lower Secondary Curriculum (1998). He explained that History is a subject that can stimulate the process of thinking. This process of thinking can not only be critically applied but also analytically.

According to the Ministry of Education, 2001b, the structure of Educational education disciplines is divided into five branches. First, it encompasses inquiries in history, resource accumulation, historical thinking skills, historical clarity and historical understanding. In the aspect of History Thought Skills, the ministry has outlined five key elements that should be applied by the History teachers to students. The main element is to use chronological skills. Chronology will make it easier for students to understand past, present and future use in the order of a historical event. Second is the exploration of evidence. Exploration of evidence will allow students to use the first and second resource identification skills. Even though exploration of evidence, it can also help students to make judgments between these two sources as well as obtain accurate historical information from them.

The third element is the execution of interpretation. Interpretation means students will be given the opportunity to make their own interpretation in understanding something. This skill enables students to better understand the relationship between historical facts and historical interpretation. This is supported by Swartz and McGuiness (2014). Both of these researchers state that the interpretation skills are not only allowing students to make differing views from different perspectives but it is also a first step in shaping a better society in the future. Next is about imagination skills. Generally, imagination is an effort to encourage students to imagine a situation in the historical events studied. The imagination skills are usually done in two ways, visually and through empathy.

The last element is to rationalize. Rationalization is a process that involves the use of common sense in making rational decisions especially in resolving a problem. In this case, students need to have the skills in collecting data, making hypotheses, determining significant evidence and making inferences of the collected data. All of these key elements are aimed at achieving the objectives as embodied in the Teaching and Learning Teaching Module. Ministry of Education Malaysia, 2001c: 3 has outlined these five objectives. First is to produce creative 
and critical learners, understand historical features, see an event empathy and explore complex and abstract ideas with teacher guidance and help students in understanding how historians build past events using historical evidence to determine the significance an event.

Basically, the application of this Historical Thinking Skill is located under the responsibility of the History teacher in translating the curriculum contained in the syllabus. The way to attract students is to learn the history of History in the real sense. Teachers can start with the most fundamental thing by introducing clear historical concepts such as for cause and effect, chronology and interpretation skills. According to Twells (2015), the process of teaching and learning History requires the commitment of teachers. In this case, teachers should not be subject to material only from textbooks. The process of teaching and learning should involve the students in the use of relevant multimedia and the use of other teaching aids.

Not only that, teachers are encouraged to improve their pedagogical skills. This is in line with what Eagen and Kauchack (2001) state. According to both, History teachers do not just have to focus on solving the facts but they also need to diversify their creativity in pedagogical skills. This is to encourage students to participate and improve their thinking skills, especially in the context of linking events that have taken place over the same period of time. If history teachers do not use the approach then it is not surprising that many students are less interested in History and eventually cause them to feel bored and create a dead man curriculum as Ahmad, (2009) emphasizes.

\section{METHOD}

This study aims to examine the readiness of the History teachers in secondary schools in the district of Batu Pahat, Johor in applying the Historical Thinking Skills to students. This is in line with the mission and objectives contained in the KSSM History teaching. Based on the question of the study, therefore, the objective of this study is to review the level of readiness of teachers in applying the Historical Thinking Skills based on their specialization subjects and to review the level of readiness of teachers in applying Historical Thinking Skills based on teaching experience.

The model of the study in this article uses the model as it was organized by the Ministry of Education (2001b). Through this model, the ministry has explained that there are five elements in the History of Thought Skills. The first element is through chronological skills, followed by an exploration of evidence, interpretation skills, imagination skills and the last rationalization. The sample of this study was composed of History teachers in secondary schools around the district of Batu Pahat, Johor. The involved History teachers consist of those who teach History subjects from Form 1 to Form 5 students. However, only one sample was taken to represent the population. This is due to limitations on costing and timing. 
The research data were obtained through a questionnaire distributed to the respondents to determine the validity and reliability of the question items. The study on the level of readiness of teachers in history in realizing the skills of historical thinking to students is a quantitative study by using survey method. This data collection process was collected through the circulation of a set of questionnaires. The questionnaire was distributed to research respondents by researchers. The questionnaire was designed to respond to the Likert scale which was divided into five categories. The questionnaire is divided into two parts: Part A and Part B. Part A are about the background of respondents. It consists of teaching experience and their specialization subjects. The items in Part B include some constructs: Preparation of Teacher's Procedural Knowledge and Preparation of Pedagogical Knowledge.

\section{RESULT AND DISCUSSION}

Table 1. Readiness level according to mean interpretation by Wiersma

\begin{tabular}{|c|c|}
\hline Score & Readiness Level \\
\hline $1.00-2.33$ & Weak \\
\hline $2.34-3.67$ & Moderate \\
\hline $3.68-5.00$ & High \\
\hline
\end{tabular}

To assess the level of readiness, this study was conducted using the mean interests by Wiersma, 1995 where values 1.00 to 2.33 represent weak levels, 2.34-3.67 are moderate while 3.68 to 5.00 are high.

Table 2. Mean Difference between Knowledge Level and Specification Subject

\begin{tabular}{|ll|l|l|}
\hline \multicolumn{2}{|c|}{ SPECIFICATION } & \multicolumn{1}{|c|}{ KPP } & \multicolumn{1}{c|}{ KPP1 } \\
\hline HISTORY & Mean & 4.3444 & 4.4583 \\
& $\mathrm{~N}$ & 18 & 18 \\
& Std. Deviation & .47265 & 41789 \\
\hline OTHERS SUBJECT & Mean & 4.4778 & 4.3542 \\
& $\mathrm{~N}$ & 12 & 12 \\
& Std. Deviation & 34446 & .26561 \\
\hline Total & Mean & 4.3978 & 4.4167 \\
& $\mathrm{~N}$ & 30 & 30 \\
& Std. Deviation & 42471 & .36308 \\
\hline
\end{tabular}

Table 2 shows the mean difference in knowledge readiness between History and nonHistory Specification Subjects. Based on the table found that teachers who took the History option were more dominant than the aspect of Pedagogical Knowledge Readiness at mean 4.4583 while non-option teachers had a mean of 4.3542. However, from the aspect of Procedural Readiness, it is found that teachers are not a History option better to apply it at 4.4778 min compared to History option teachers at only a mean of 4.344 for Procedural 
Readiness. Overall, the level of readiness of teachers to apply the Historical Thinking Skills based on specialization is at a high level.

Table 3. Mean Difference Level of Knowledge Readiness between Experiences in Teaching

\begin{tabular}{|c|c|c|c|c|c|}
\hline \multicolumn{2}{|c|}{ EXPERIENCE } & \multicolumn{2}{|r|}{ KPP } & \multicolumn{2}{|c|}{ KPP1 } \\
\hline LESS THAN 10 YEARS & $\begin{array}{l}\text { Mean } \\
\mathrm{N} \\
\text { Std. Deviation }\end{array}$ & 79 & $\begin{array}{l}4.18 \\
11 \\
.412\end{array}$ & $\begin{array}{l}73 \\
49\end{array}$ & $\begin{array}{l}4.22 \\
11 \\
.289\end{array}$ \\
\hline MORE THAN 10 YEARS & $\begin{array}{l}\text { Mean } \\
\mathrm{N} \\
\text { Std. Deviation }\end{array}$ & 93 & $\begin{array}{l}4.51 \\
19 \\
.391\end{array}$ & $\begin{array}{l}63 \\
23\end{array}$ & $\begin{array}{l}4.52 \\
19 \\
.362\end{array}$ \\
\hline Total & $\begin{array}{l}\text { Mean } \\
\mathrm{N} \\
\text { Std. Deviation }\end{array}$ & 78 & $\begin{array}{l}4.39 \\
30 \\
.424\end{array}$ & $\mid \begin{array}{l}67 \\
08\end{array}$ & $\begin{array}{l}4.41 \\
30 \\
.363\end{array}$ \\
\hline
\end{tabular}

Table 3 shows the mean difference in the readiness of knowledge between the experience of a history teacher who taught more than 10 years and less than 10 years. Based on the table we find that teachers with more than 10 years of teaching experience are more dominant in both aspects studied. Procedural Knowledge Readiness for teachers over 10 years is at $4.5193 \mathrm{~min}$ compared to only 4.1879 for teachers less than 10 years. The availability of Pedagogical Knowledge for experienced teachers over 10 years is at a mean of 4.5263. In total, the average level of readiness of teachers in applying the Historical Thinking Skills according to the teaching experience is at a high level.

Table 4. Mean the Overall Difference for Teaching Experience Independent Sample Test

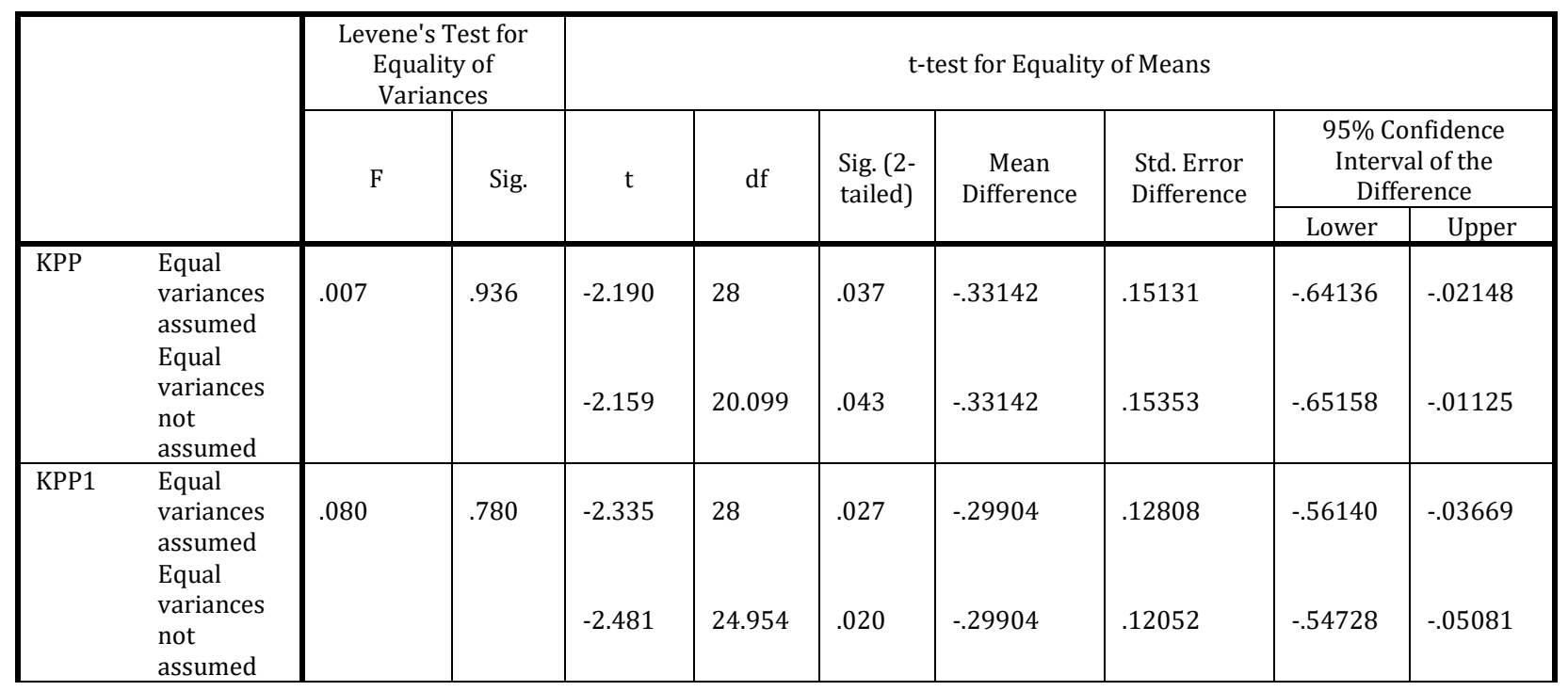


Table 4 shows the t-test 2 samples are independent of the overall difference in teacher experience. For Procedural Knowledge Skills, the significant value is 0.037 while for Pedagogical Knowledge Skills, its significant value is at 0.027. Based on the table finds that the second null hypothesis is rejected. This means that there is a significant difference between teaching experience and the level of teacher's readiness. This is because the significant value of each construct is less than $<0.05$. Thus, teacher experience shows that the more experienced teachers teaching in History, the level of readiness in applying historical thinking skills to students is high.

TABLE 5: Mean the Overall Difference of Specification of Subjects

\begin{tabular}{|c|c|c|c|c|c|c|c|c|c|c|}
\hline & \multicolumn{2}{|c|}{$\begin{array}{c}\text { Levene's Test for } \\
\text { Equality of } \\
\text { Variances }\end{array}$} & \multicolumn{7}{|c|}{ t-test for Equality of Means } \\
\hline & & \multirow[t]{2}{*}{$\mathrm{F}$} & \multirow[t]{2}{*}{ Sig. } & \multirow[t]{2}{*}{$\mathrm{t}$} & \multirow[t]{2}{*}{$\mathrm{df}$} & \multirow{2}{*}{$\begin{array}{l}\text { Sig. } \\
(2- \\
\text { tailed) }\end{array}$} & \multirow[t]{2}{*}{$\begin{array}{c}\text { Mean } \\
\text { Difference }\end{array}$} & \multirow{2}{*}{$\begin{array}{l}\text { Std. Error } \\
\text { Difference }\end{array}$} & \multicolumn{2}{|c|}{$\begin{array}{l}95 \% \text { Confidence } \\
\text { Interval of the } \\
\text { Difference }\end{array}$} \\
\hline & & & & & & & & & Lower & Upper \\
\hline KPP & $\begin{array}{l}\text { Equal } \\
\text { variances } \\
\text { assumed } \\
\text { Equal } \\
\text { variances not } \\
\text { assumed }\end{array}$ & 2.895 & .100 & $\begin{array}{l}-.838 \\
-.893\end{array}$ & 28 & .409 & -.13333 & $\begin{array}{l}.15910 \\
.14933\end{array}$ & $\begin{array}{l}-.45923 \\
-.43937\end{array}$ & $\begin{array}{l}.19257 \\
.17270\end{array}$ \\
\hline KPP1 & $\begin{array}{l}\text { Equal } \\
\text { variances } \\
\text { assumed } \\
\text { Equal } \\
\text { variances not } \\
\text { assumed }\end{array}$ & .885 & .355 & .764 & 28 & .451 & .10417 & .13629 & $\begin{array}{l}-.17501 \\
-.15153\end{array}$ & .38335 \\
\hline
\end{tabular}

Table 5 shows the mean t-test of the overall difference between the areas of specialization. For Procedural Knowledge Skills, the significant value is 0.409 while for Pedagogical Knowledge Skills, the significant value is at 0.451 . Based on the table finds that the second hypothesis null was rejected. This means that there is no significant difference between specialization areas and non-specialization with the level of teacher's readiness. This is because the significant value of each construct is greater than $>0.05$ relative to the significant value of $<0.05$. Therefore, the area of specialization or teacher options indicates that it does not affect the level of readiness of teachers in applying historical thinking skills to students.

The result of the study shows that the level of readiness of the history teachers in some aspects including procedural knowledge, pedagogical knowledge, teaching aids knowledge and total teacher attitude is at a high level of almost all items recording meanings above 4.0 and above. The value of this readiness is measured based on the degree of the tendency by Wiersma, 1995 where the average height or readiness is at mean 3.68 to 5.00 .

The results of the t-test of two independent samples showed that the mean difference of readership level of History teachers in the context of experience found that there was a significant mean difference between teaching experience and the level of knowledge readiness 
of teachers. This means that teachers with more than 10 years of experience are more prepared to apply historical thinking skills than those with less than 10 years of experience. This is in line with what Bage (2000) states. His studies show the teaching of history teachers to be more effective in terms of their length of service as teachers. The longer the teaching, the more effective the teacher's teaching. Bage's studies are also supported by a study conducted by Husbands (2011) when he finds experienced teachers in the United Kingdom more likely to carry out the lesson by giving preference to procedural knowledge in history teaching.

For the level of teacher readiness in specialization and non-specialization, results from the findings show that there is no significant mean difference between specialization areas and the level of readiness of teachers in applying Historical thinking skills to students. In this regard, Husbands (2011) states that the knowledge of the history of the teacher is quite a lot, it still does not guarantee the teaching will be effective. It can be argued that the specialization area does not affect the level of readiness of the History teachers although basically, the teacher holds a degree in History. This is because the needs of students in the classroom are always diverse and the teacher should always be willing to modify their historical knowledge according to the needs and conditions of the students. This is also supported by Endacott and Brooks (2013), the effectiveness of the teaching and learning process is based on the extent to which the History teachers apply the skills he has with students' situations and attitudes in connecting past and storytelling to attract students.

These are composed of a research result as displayed as words, tables, figures, and photographs. The limitation of using graphics and photos will be appreciated. However, it needs to be displayed if it can describe a better explanation for research result. All of Figures and tables should be given continuing numbers and must be referred in the article.

This section is the main part of the article the results of research and is usually the longest part of an article. The results of the research presented in this section are the result of a "clean". The process of data analysis such as statistical calculations and testing process or other processes for the achievement of its research.

This section is also a major part of the research articles and is also usually the longest part of an article. Discussion of the research presented in this section is the result. The process of data analysis such as statistical calculations and testing process or other processes for the achievement of its research.

\section{CONCLUSION}

As the conclusion, the findings of this survey found that the level of preparedness of respondents in all aspects studied is at a high level without being influenced by whether the teacher is a History option teacher or not. However, it is limited in terms of how long the History 
teachers experience in teaching and learning. If we want to ensure that the application of the History of Thought Skills can be fully applied to students, the ministry should provide teacher training that provides training for teachers to better understand the concept of History. Not only that, Historian teachers are also advised to raise specific knowledge about how students build their History understanding. This is necessary as each student has different levels and capabilities.

\section{REFERENCES}

Ahmad, A. R. (2009). Inovasi dan Kepelbagaian Kaedah Dalam Pengajaran dan Pembelajaran. Dlm. Isjoni \& Abdul Razak Ahmad. Transformasi Pengajaran dan Pembelajaran Sejarah. Pekan Baru: Cendikia Insan.

Bage, G (1999). Narrative Matters: Teaching History through Story. London: Routledge Falmer.

Eggan, P. D \& Kauchack, D. P (2001). Strategies for Teachers: Teaching Content and Skills. Upper Saddlle River, NJ: Prentice Hall.

Endacott, J. \& Brooks, S. (2013). Theoretical and Practical Model for Promoting Historical Empathy. Volume 8 Number 1. Spring.

Husbands. (2011). Progression in Historical Understanding among Students age 7-14. New York University Press.

Kementerian Pendidikan Malaysia. (2001-b). Huraian Sukatan Mata Pelajaran Sejarah Tingkatan 1,2 dan 3.

Kementerian Pendidikan Malaysia. (2001-c).Modul Latihan dan Pembelajaran Sejarah.

Mohamad, M. (1998). Analisis Kemahiran Pemikiran Sejarah dalam Bahan Kurikulum Peringkat Menengah Rendah. Tesis Sarjana, Universiti Kebangsaan Malaysia.

Awang, MM, et al. (2016). Historical Thinking Skills among Pre-Service Teachers In Indonesia and Malaysia. Scientific Research Publishing.

Seixas, P. (1993). Historical Understanding Among Adolescents in a Multicultural Setting. Curriculum Inquiry.

Swartz, R. \& Mcguiness, C. (2014). Developing and Assessing Thinking Skills. Find Report of Thinking Skills Project. Boston and Northern Ireland: The International Baccalaureate Organization.

Twells, A. (2015). 'More Than Gaining Mark': Students as Partners and Co-Partners in Public History and Community Engagement in D. Ludvinggson, \& A. Booth (Eds). Enriching History Teaching and Learning. Sweden: Linkoping University.

VanSledright, B. A. On The Importance of Historical Positionality to Thinking About and Teaching History. The Journal of Social Education, Special Issue on Historical Thinking.

Wineburg, S. (1998). A Partial History: An Essay Review of Teaching and Learning History in Elementary Schools. Teaching and Teacher Education, 14(2). 
Wineburg, S. (2001). Historical Thinking and Other Unnatural Acts: Charting The Future of Teaching The Past. Philadephia: Temple University Press.

Nordin, W.M.Z.M. (1991). Falsafah Pendidikan Sejarah: Pendidikan Sejarah di Sekolah Rendah dan Sekolah Menengah (KBSR/KBSM): Objektif dan Pencapaian. Kuala Lumpur.

Aziz, Z. \& Ismail, N.A.N. (2007). Kajian Tinjauan Kesedian Guru Sejarah dalam Kemahiran Pemikiran Sejarah. Jurnal Pendidikan 32. 119-137. 